\title{
PEMANFAATAN TEKNOLOGI DIGITAL DALAM KEGIATAN PEMBELAJARAN
}

\author{
Nandang Hidayat ${ }^{\text {a) }}$, Husnul Khotimah ${ }^{\text {b) }}$ \\ ${ }^{a)}$ Universitas Pakuan, Bogor, Indonesia \\ b) Institut Pembina Rohani Islam Jakarta, Jakarta, Indonesia \\ e-mail korespondensi : mr.nandanghidayat@gmail.com
}

diterima: 21 Oktober 2018; direvisi: 02 Januari 2019; disetujui: 04 Februari 2019

\begin{abstract}
This research study aims to systematically review a variety of digital technologies that are currently developing so rapidly to be optimally utilized according to the ability of teachers and technological devices owned by schools, teachers, and students. This study uses the method of review of integrative literature. This method combines various empirical and research-based articles, books, and other published literature on digital competencies and their use in 21 st century education. The literature research concludes: 1) Digital literacy is the awareness, attitude, and ability of individuals to properly use tools and digital facilities to identify, access, manage, integrate, evaluate, analyze, and synthesize digital resources, build new knowledge, make media expressions, and communicate with others, in the context of certain life situations, to enable constructive social action; 2) Digital competency is a set of knowledge, skills, attitudes needed when using ICT and digital media for various needs; 3) Digital technology that can be used by schools / teachers in the learning process including interactive whiteboards (IWB), software applications, Web 2.0, and social media; and 4) Utilization of digital technology in learning can increase students' interest and motivation in learning, the quality of learning processes, and learning outcomes, but need to pay attention to various aspects of the ability of human resources, security, and health of teachers and students.
\end{abstract}

Keywords: digital technology, digital literacy, digital competence, learning process

\section{PENDAHULUAN}

Teknologi informasi dan komunikasi (TIK) telah menjadi entitas umum di semua aspek kehidupan. Selama dua puluh tahun terakhir penggunaan TIK telah secara mendasar mengubah praktik dan prosedur dari hampir semua bentuk usaha dalam bisnis dan pemerintahan. Pendidikan adalah kegiatan yang sangat berorientasi sosial dan pendidikan berkualitas secara tradisional dikaitkan dengan guru yang kuat yang memiliki tingkat kontak pribadi yang tinggi dengan peserta didik. Penggunaan TIK dalam pendidikan cocok untuk lebih banyak pengaturan pembelajaran yang berpusat pada siswa. Tetapi dengan dunia bergerak cepat ke media digital dan informasi, peran TIK dalam pendidikan menjadi semakin penting dan pentingnya ini akan terus tumbuh dan berkembang di abad ke-21 [1].

Dalam beberapa tahun terakhir, kompetensi digital telah menjadi konsep kunci dalam diskusi tentang jenis keterampilan dan pemahaman yang dibutuhkan peserta didik dalam masyarakat pengetahuan. Namun, telah ditafsirkan dalam berbagai cara (misalnya, Digital Literacy, Digital Competence, eLiteracy, e-Skills, eCompetence, Computer literacy, dan literacy Media) dalam dokumen kebijakan, dalam literatur akademik, dan dalam pengajaran, pembelajaran, dan praktik sertifikasi. Semua istilah ini menyoroti kebutuhan untuk menangani teknologi di era digital [2], [3].

Pesatnya perkembangan teknologi digital telah memberi pengaruh besar terhadap dunia pendidikan. Ada dorongan kuat yang menuntut guru untuk "literasi digital" dan memanfaatkan teknologi digital kedalam kegiatan pembelajaran. Pemanfaatan teknologi digital dalam pembelajaran dapat diartikan sebagai sistem pemrosesan digital yang mendorong pembelajaran aktif, konstruksi pengetahuan, inquiri, dan eksplorasi pada pada diri peserta didik, serta memungkinkan untuk komunikasi jarak jauh dan berbagi data yang terjadi antara guru dan/atau peserta didik di lokasi kelas fisik yang berbeda [4]. Hal ini merupakan pemanfaatan teknologi yang diperluas dari sistem pengiriman informasi belaka dan juga memperjelas peran dan penggunaannya yang lebih luas di ruang kelas yang berbeda, seluruh sekolah, dan pusat pembelajaran lainnya.

Teknologi digital yang mencakup teknologi informasi dan komunikasi baru seperti Internet, dunia game online, kecerdasan buatan, robotika, dan pencetakan 3D membutuhkan literasi baru. Dalam beberapa tahun terakhir, kompetensi digital telah menjadi konsep kunci dalam diskusi tentang jenis keterampilan dan pemahaman yang dibutuhkan peserta didik dalam Masyarakat Pengetahuan [5].

Wilayah cakupan pendidikan berubah dengan cepat [6]. Internet memiliki efek multiplikasi yang memungkinkan diseminasi dan pembangkitan teknologi baru dengan konsekuensi pendidikan, sosial, dan budaya. Teknologi digital baru, misalnya, dapat mengintegrasikan gambar suara dan bergerak, bahasa lisan dan tulisan, dan objek 3D, dll. Digunakan dalam konteks pendidikan, masing-masing perangkat digital ini memiliki kemampuan, penggunaan, dan batasan khusus. Oleh karena itu, teknologi informasi dan komunikasi baru membutuhkan literasi baru (Leu, Zawilinski, Castek, Banerjee, Housand, Liu \& O’Neil, 2007). 
Dalam lanskap pendidikan baru ini, banyak pelajar memasuki pendidikan lebih lanjut dan lebih tinggi tanpa keterampilan yang mereka butuhkan untuk menerapkan teknologi digital ke pendidikan [7]. Memperluas dan meningkatkan kompetensi digital merupakan komponen penting dalam pengembangan lulusan yang dapat kompetitif dalam mendapat pekerjaan. Karena $90 \%$ pekerjaan baru akan membutuhkan keterampilan digital yang sangat baik, mereka yang tidak memiliki keterampilan TIK yang memadai akan berada pada posisi yang kurang menguntungkan di pasar tenaga kerja dan memiliki sedikit akses ke informasi (Komisi Eropa, 2013) Definisi kompetensi digital mencakup dua orientasi utama, yaitu keterampilan dasar (terhubung dengan pengetahuan), dan soft skill (berhubungan dengan sikap dan keterampilan). Dalam hal ini, kompetensi digital mendukung dan membantu proses integrasi sosia [8].

Artikel ini tidak bermaksud untuk mengenyampingkan upaya yang selama ini telah dilakukan guru khususnya guru sekolah dasar dan menganggap proses pembelajaran selama ini tidak berkualitas. Artikel ini bertujuan untuk secara sistematis meninjau berbagai teknologi digital yang saat ini berkembang begitu pesat untuk dimanfaatkan secara optimal sesuai kemampuan guru dan perangkat teknologi yang dimiliki sekolah, guru, dan peserta didik. Kajian dalam artikel ini akan memungkinkan kita tidak hanya akan melahirkan dan memajukan generasi pengetahuan tetapi juga untuk mengidentifikasi aspek-aspek kunci dari kompetensi penting ini untuk pendidikan di abad ke-21.

\section{METODE PENELITIAN}

Untuk mencapai tujuan penelitian ini, kajian tentang pemanfaatan teknologi digital dalam proses pembelajaran dilakukan dengan menggunakan metode tinjauan literatur integratif. Dengan menggunakan metode tersebut, kami melakukan penelaahan literatur melalui proses meninjau, mengkritik, dan mensintesis literatur representatif mengenai suatu topik dengan cara yang terintegrasi sedemikian rupa sehingga dihasilkan kerangka kerja dan perspektif baru (Callahan, 2010). Metode ini menggabungkan berbagai artikel berbasis empiris dan penelitian, buku, dan literatur lain (misalnya situs web konferensi dan proses yang dipublikasikan) tentang kompetensi digital dan pemanfaatannya dalam pendidikan abad 21 .

\section{HASIL DAN PEMBAHASAN}

\section{Pengertian literasi digital dan kompetensi digital}

Kompetensi digital dan literasi digital sangat terkait tetapi tidak identik [5]. Kompetensi digital dapat dianggap sebagai konsep multi-faceted yang muncul dari beberapa latar belakang [9], [10]. Kompetensi digital dianggap sebagai kompetensi inti dalam makalah kebijakan tetapi belum merupakan konsep yang stabil [10], [11]. Pendapat berbeda ini berarti masih belum ada panduan penilaian yang jelas untuk kompetensi digital [12], [13]. Sementara beberapa merasakan kompetensi digital sebagai penggunaan teknis ICT, yang lain mendefinisikannya secara lebih luas sebagai aplikasi pengetahuan atau keterampilan abad ke-21 [5].

Literasi digital merupakan sebuah konsep yang terkait erat dengan kompetensi digital, diperkenalkan oleh Paul Gilster dalam bukunya tahun 1997 dengan nama yang sama. Konsep ini dipahami sebagai kombinasi keterampilan teknisprosedural, kognitif dan emosional-sosial. Menurutnya, literasi digital adalah kemampuan untuk memahami dan menggunakan informasi dalam berbagai format dari berbagai sumber ketika disajikan melalui komputer [14]. Literasi digital (Jones-Kavalier \& Flannigan, 2006) mewakili kemampuan seseorang untuk melakukan tugas secara efektif dalam lingkungan digital, di mana "digital" berarti informasi yang direpresentasikan dalam bentuk angka dan terutama untuk digunakan oleh komputer [15]. Perhatian utama literasi digital adalah membaca dan menulis dengan teknologi baru - teknologi yang melibatkan semiotik representasi tertulis - mengakui bahwa teks di layar selalu menggabungkan penulisan dengan mode representasi lainnya" [16].

Pada awalnya Eshet-Alkalai (2004) menyatakan "literasi digital melibatkan lebih dari sekadar kemampuan untuk menggunakan perangkat lunak atau mengoperasikan perangkat digital; ini mencakup berbagai macam keterampilan kognitif, motorik, sosiologis, dan emosional yang kompleks, yang dibutuhkan pengguna agar berfungsi secara efektif dalam lingkungan digital" [17]. Ia juga mengusulkan model konseptual holistik lima-keterampilan untuk konsep ini, dengan alasan bahwa model mencakup sebagian besar keterampilan kognitif yang digunakan pengguna dalam lingkungan digital: (a) berpikir digital fotovisual; (b) reproduksi pemikiran digital; (c) percabangan pemikiran digital; (d) informasi digital thinking; dan (e) pemikiran digital sosio-emosional. Karena cepatnya evolusi teknologi multimedia dan game, Eshet-Alkalai juga menambahkan pemikiran digital waktu nyata [18].

Literasi Digital adalah "kesadaran, sikap, dan kemampuan individu untuk secara tepat menggunakan alat dan fasilitas digital untuk mengidentifikasi, mengakses, mengelola, mengintegrasikan, mengevaluasi, menganalisis, dan menyintesis sumber daya digital, membangun pengetahuan baru, membuat ekspresi media, dan berkomunikasi dengan orang lain, dalam konteks situasi kehidupan tertentu, untuk memungkinkan tindakan sosial yang konstruktif; dan merenungkan proses ini" [19]. Kemudian, Martin (2009) mengusulkan tiga "level" atau tahapan untuk pengembangan literasi, yaitu: Level I kompetensi digital yang memcakup keterampilan, konsep, pendekatan, sikap, dan lainnya; Level II penggunaan digital yang mencakup aplikasi profesional/disiplin; dan Level III tansformasi digital yaitu inovasi/kreativitas. Dalam hal ini, Martin (2009) berpendapat bahwa definisi ini menyarankan mendiskusikan literasi digital hanya pada level II atau III; kompetensi digital adalah persyaratan dan pendahulu literasi digital tetapi tidak dapat digambarkan sebagai literasi digital.

Definisi lain dikemukakan oleh Calvani, Cartelli, Fini, \& Ranieri (2008), bahwa kompetensi digital melibatkan 
"mampu mengeksplorasi dan menghadapi situasi teknologi baru dengan cara yang fleksibel, untuk menganalisis, memilih dan secara kritis mengevaluasi data dan informasi, untuk memanfaatkan potensi teknologi untuk mewakili dan memecahkan masalah dan membangun pengetahuan bersama dan kolaboratif, sambil menumbuhkan kesadaran akan tanggung jawab pribadi seseorang dan menghormati hak/kewajiban timbal balik ". Juga, definisi yang diusulkan meraka menekankan pada ko-eksistensi dimensi yang dicirikan baik pada tingkat teknologi, kognitif, dan etika, serta integrasi ketiganya [22]. Sebuah penelitian terbaru yang bertujuan untuk mengidentifikasi, memilih dan menganalisis kerangka kerja saat ini, mengidentifikasi kompetensi berikut: Manajemen informasi, kolaborasi, komunikasi dan berbagi, penciptaan konten dan pengetahuan, etika dan tanggung jawab, evaluasi dan pemecahan masalah, dan operasi teknis [2].

Berdasarkan kajian literatur di atas dapat disimpulkan bahwa kompetensi digital adalah seperangkat pengetahuan, keterampilan, sikap (termasuk kemampuan, strategi, nilai dan kesadaran) yang diperlukan saat menggunakan TIK dan media digital untuk melakukan tugas; menyelesaikan masalah; menyampaikan; mengelola informasi; berkolaborasi; buat dan bagikan konten; dan membangun pengetahuan secara efektif, efisien, tepat, kritis, kreatif, mandiri, fleksibel, etis, reflektif untuk bekerja, bersantai, partisipasi, belajar, bersosialisasi, mengkonsumsi, dan memberdayakan diri.

\section{Teknologi digital yang dapat dimanfaatkan dalam proses pembelajaran}

Dalam perkembangan teknologi global, e-learning merupakan bentuk teknologi informasi yang dapat diterapkan dalam bidang pendidikan. e-Learning merupakan suatu transformasi proses belajar mengajar yang ada di sekolah ke dalam bentuk digital. Dengan menggunakan teknologi e-Learning proses belajar mengajar dapat berlangsung secara live ataupun virtual [23]. Ada pula yang menafsirkan e-learning sebagai bentuk pendidikan jarak jauh yang dilakukan melalui media internet [24].

Berbagai inovasi dalam pembelajaran berbasis media digital menunjang pembelajaran lebih efektif dan efisien [25]. Pemanfaatan teknologoi digital dalam pembelajaran memungkinkan peserta didik mengalami pengalaman pembelajaran nyata dan dapat berinteraksi dengan individu lain tanpa perlu bertatap muka [26]. Para reformis pendidikan menunjukkan bahwa munculnya teknologi digital sebagai teknologi baru akan secara radikal mengubah apa yang orang pelajari, bagaimana mereka belajar, dan di mana mereka belajar [27]. Lebih lanjut Warschauer (2007) berdasarkan hasil kajian leteraturnya menjelaskan bahwa sifat pembelajaran digital dipengaruhi oleh peran sosial, budaya, dan faktor ekonomi dalam membentuk dan menghambat transformasi pendidikan di era digital.

Pemanfaatan teknologi digital dalam proses pembelajaran merupakan langkah berani menunju dunia baru. Langkah berani ini membutuhkan inovasi, kreativitas, dan keuletan, dan keberanian untuk menerima bahwa sifat pengetahuan telah berevolusi dalam lanskap digital [28].
Hasil studi internasional menunjukkan bahwa strategi pengajaran untuk kompetensi abad ke-21 sering tidak dilaksanakan dengan baik dalam praktik pendidikan yang sebenarnya. Alasan untuk ini termasuk kurangnya integrasi kompetensi abad 21 dalam kurikulum dan penilaian, persiapan guru yang tidak memadai dan tidak adanya perhatian sistematis untuk strategi mengadopsi praktik pengajaran dan pembelajaran inovatif [29]. Untuk itu, para guru harus "literasi digital" dan berupaya untuk meningkatkan kompetensi digitalnya, serta mengimplementasikannya dalam praktik pembelajaran.

Berikut adalah sejumlah teknologi digital yang dapat dimanfaatkan guru dalam meningkatkan kualitas proses pembelajaran yang dicirikan oleh adanya pembelajaran aktif, konstruksi pengetahuan, inquiri, dan eksplorasi pada pada diri peserta didik baik saat berada di dalam kelas secara fisik maupun sedang berada jauh dari jangkauan guru.

1. Interactive Whiteboards (IWB). Teknologi ini memungkinkan gambar dari komputer untuk ditampilkan melalui proyektor digital, ke papan besar atau bisa juga ke dinding. Pengguna dapat berinteraksi dengan konten di papan menggunakan jari atau stylus. Selama dekade terakhir, papan tulis interaktif telah menjadi alat pengajaran dan pembelajaran yang populer, terutama di ruang kelas sekolah dasar. Studi penelitian dari laporan literatur terbaru tentang tingkat motivasi siswa yang tinggi, antusiasme guru dan dukungan seluruh sekolah yang terkait dengan alat-alat teknologi ini. Banyak penelitian hingga saat ini telah melaporkan potensi papan tulis interaktif untuk meningkatkan kualitas proses belajar mengajar dengan meningkatkan tingkat interaksi, komunikasi dan kolaborasi [30].

2. Aplikasi Perangkat Lunak. Beragam aplikasi yang sudah tersedia maupun mengembangkan sendiri untuk keperluan pembelajaran. Aplikasai tersebut dirancang untuk beroperasi di perangkat seluler seperti ponsel cerdas dan komputer tablet. Pemanfaatan aplikasi perangkat lunak dapat memfasilitasi lingkungan belajar pribadi yang berguna atau memang penting untuk pembelajaran di masa depan. Pemanfaatan aplikasi perangkat lunak akan mendorong perubahan wajah pendidikan dan berbagai cara di mana yang disebut peserta didik saat ini yang sering juga disebut generasi net atau milenial menggunakan teknologi untuk belajar. Aplikasi perangkat lunak jika digunakan dalam pembelajaran dapat mendukung pembelajaran tersebut yang memungkinkan peran individu dalam mengatur pembelajarannya sendiri. Selain itu, pembelajaran akan berlangsung dalam konteks dan situasi yang berbeda dan tidak tidak mampu disediakan oleh penyedia pembelajaran tunggal. Terkait dengan ini adalah pengakuan yang semakin meningkat akan pentingnya pembelajaran informal [31].

3. Web 2.0 yang mengacu pada generasi kedua dari World Wide Web. Web 2.0 mencakup fitur dan fungsionalitas yang sebelumnya tidak tersedia, misalnya. podcast, blog, wiki, RSS ((Rich Site Summary). RSS digunakan untuk 
memperbarui konten web yang berubah secara berkala), jejaring sosial dan penandaan [32].

4. Media sosial. Di era digital saat ini, jejaring sosial mengambil peran sentral dalam pembelajaran di lingkungan informal. Media sosial menawarkan peserta didik muda seperti sekolah dasar untuk mengeksplorasi tanggapan kompleks dan partisipasi dengan konten budaya. Tentu saja dalam penerapannya perlu dipertimbangkan transformasi dalam literasi digital dan proses di mana peserta didik muda dapat terhubung dengan pengetahuan di lingkungan pembelajaran informal untuk menjadi peserta budaya yang aktif [33].

\section{Manfaat teknologi digital dalam pembelajaran}

Manfaat potensial dari teknologi digital dalam proses pembelajaran diantaranya adalah: Pertama, Penggunaanya dapat mendorong praktik dialogis dan emansipatori peserta didik dalam kegiatan pembelajaran bahkan mendorong mereka menjadi proaktif dalam belajar. E-learning sekarang merupakan komponen penting dari pendidikan. Dengan menggunakan contoh dari seluruh dunia e-learning memperkaya pengalaman belajar; pembelajaran diperpanjang; memberdayakan pembelajaran; teori belajar yang berkembang; pembelajaran emansipatif; dan penciptaan komunitas [34]. Penggunaan teknologi digital memungkinkan peserta didik lebih dahulu mendapat informasi baru terkait dengan konten bahan ajar ketimbang guru. Praktik dialogis adalah proses pembelajaran dimana siswa aktif, terlibat belajar secara intens, dan memberdayakan peserta didik dalam percakapan dari mana pembelajaran muncul. Misalnya, pelajar yang bekerja pada program pemodelan matematika dapat mulai melakukan percakapan tentang apa yang mereka lihat di layar komputer atau ponsel cerdas mereka tanpa harus bergantung pada terminologi yang mungkin belum mereka miliki (lihat 'itu', apa yang terjadi jika Anda melakukan 'ini' ?) Guru kemudian dapat menambahkan bahasa yang sesuai ke dalam percakapan ketika proyek berkembang. Praktik emansipatori pada prinsipnya adalah upaya mengakomodasi ide-ide individu peserta didik yang melampaui pembelajaran yang ditentukan oleh guru/silabus saat mereka memanfaatkan pengetahuan yang diperoleh di luar konten pendidikan secra formal untuk membangun pemahamannya. Misalnya, dalam pelajaran musik, pelajar dapat menggunakan pengetahuan dan keahlian mereka sendiri dalam memainkan alat musik atau menggunakan teknologi untuk merekamannya sendiri (mungkin menggunakan ponsel mereka). Mereka kemudian dapat membawa ide-ide yang telah mereka buat di rumah atau di tempat kurusus musik yang diikutinya. Dalam hal ini, guru memanfaatkan inisiatif tersebut untuk memperkaya konten pembelajaran sehingga menjadi kontekstual.

Kedua, teknologi yang berbeda dapat meningkatkan kualitas proses pembelajaran [1] dengan menambah dan menghubungkan kegiatan belajar dengan kegiatan belajar yang terjadi di kelas lain atau sekolah lain atau lingkungan [35]. Sebagai contoh, dalam pelajaran geografi, dua kelas di sekolah yang berbeda dapat terhubung melalui internet untuk mengeksplorasi perbedaan budaya terkait dengan masalah global tertentu seperti polusi atau pasokan energi.
Kelompok-kelompok dapat bekerja sama untuk memahami bukan hanya masalah itu sendiri tetapi dampaknya terhadap masyarakat dan individu dengan berbicara kepada orangorang secara langsung dan nyata. Hubungan dalam situasi terbatas seperti ini dapat dilakukan di seluruh tingkat kelas melalui video atau bahkan melalui pesan email, wa, atau pesan singkat.

Ketiga, Teknologi digital dapat menarik minat belajar peserta didik dan menawarkan alternatif yang berpotensi lebih menarik [36]. Pada saat yang sama penting untuk menyadari bahwa beberapa pelajar mungkin kurang percaya diri dalam belajar dengan teknologi digital atau sebaliknya menggunakannya secara berlebihan, sehingga langkah-langkah tertentu perlu diambil untuk memastikan kesetaraan akses [37].

Keempat, Pemanfaatan teknologi digital dalam proses pembelajaran menawarkan umpan balik langsung baik untuk peserta didik maupun guru..Umpan balik dalam proses pembelajaran sangat penting bagi guru untuk memperbaiki kualitas arah kegiatan pembelajaran, dan bagi peserta didik dapat memediasi hasil belajar [38] untuk memperbaiki cara, gaya, dan arah belajarnya.

\section{Tatantangan dalam pemanfaatan teknologi dalam pembelajaran}

Banyak waktu dan sumber daya saat ini diinvestasikan ke dalam teknologi dan aplikasi yang belum terbukti efektif atau efisien bila dibandingkan dengan konteks pembelajaran ruang kelas yang lebih tradisional. Guru dan sekolah perlu berpikir secara hati-hati tentang kapan, mengapa dan bagaimana menggunakan teknologi serta mengevaluasi efisiensi dan efektivitasnya. Beberapa hal yang harus menjadi pertimbangan dalam investasi teknologi dan aplikasi untuk menunjang penggunaan tekonolgi digital dalam proses pembelajaran diantaranya adalah:

1. Perhatikan kemungkinan adanya 'kesenjangan digital', yaitu kesenjangan antara mereka (guru dan peserta didik termasuk orang tua) yang memiliki akses ke teknologi digital dan internet, dan yang tidak.

2. Menerapkan dan kemudian mempertahankan teknologi itu mahal terutama karena sistem dapat dengan cepat menjadi ketinggalan zaman. Untuk itu pilihlah dengan bijak teknologi yang dapat dimanfaatkan secara optimal dalam pembelajaran dalam jangka waktu yang relatif lama.

3. Lokasi sekolah kita mungkin ada masalah dengan infrastruktur yang ada, misalnya koneksi internet mungkin tidak konsisten dan/atau lambat. Untuk hal seperti ini perlu dicari solusi dengan melibatkan ahlinya sehingga perangkat teknologi yang dimiliki sekolah dapat dimanfaatkan dengan baik dalam pembelajaran bebasis teknologi digital.

4. Keselamatan bagi peserta didik dan guru adalah tantangan utama dengan pencegahan cyber-bullying, peretasan informasi pribadi, akses ke materi ilegal atau terlarang dan gangguan dari pembelajaran (seperti jejaring sosial dan penggunaan telepon seluler) semuanya tinggi pada agenda kelembagaan. Beberapa penggunaan 
teknologi bisa berbahaya. Misalnya, cara duduk yang buruk dan kelelahan mata adalah masalah umum ketika bekerja di komputer desktop untuk waktu yang lama. Selain itu, cedera karena regangan berulang (Repetitive Strain Injury) adalah risiko yang terjadi dari tindakan berulang yang diperlukan untuk mengontrol perangkat seluler.

5. Bagaimana sekolah dapat mendukung penggunaan teknologi digital dalam kegiatan pembelajaran? Sekolah dapat memungkinkan memberi kebebasan guru dan peserta didik untuk mengeksplorasi potensi penggunaan perangkat dan sistem serta kombinasi teknologi ke dalam lingkungan digital baru.

6. Guru dapat memanfaatkan teknologi terbaik di kelas dengan mengembangkan kesadaran mereka tentang berbagai teknologi digital dan mempertimbangkan dengan cermat, bagaimana dan mengapa mereka menggunakannya untuk mendukung proses pembelajaran. Pemilihan perangkat lunak dan perangkat yang efektif hanyalah sebagian dari cerita. Pertimbangan pembelajaran apa yang akan dicapai dan bagaimana teknologi dapat membantu adalah hal yang lebih fundamental.

\section{SIMPULAN}

1. Literasi digital adalah kesadaran, sikap, dan kemampuan individu untuk secara tepat menggunakan alat dan fasilitas digital untuk mengidentifikasi, mengakses, mengelola, mengintegrasikan, mengevaluasi, menganalisis, dan menyintesis sumber daya digital, membangun pengetahuan baru, membuat ekspresi media, dan berkomunikasi dengan orang lain, dalam konteks situasi kehidupan tertentu, untuk memungkinkan tindakan sosial yang konstruktif.

2. Kompetensi digital adalah seperangkat pengetahuan, keterampilan, sikap (termasuk kemampuan, strategi, nilai dan kesadaran) yang diperlukan saat menggunakan TIK dan media digital untuk melakukan tugas; menyelesaikan masalah; menyampaikan; mengelola informasi; berkolaborasi; buat dan bagikan konten; dan membangun pengetahuan secara efektif, efisien, tepat, kritis, kreatif, mandiri, fleksibel, etis, reflektif untuk bekerja, bersantai, partisipasi, belajar, bersosialisasi, mengkonsumsi, dan memberdayakan diri.

3. Sesuai dengan kemampuan sumberdaya yang ada, teknologi digital yang dapat dimanfaatkan sekolah/guru dalam meningkatkan kualitas proses pembelajaran diantaranya adalah interactive whiteboards (IWB), aplikasi perangkat lunak, Web 2.0, dan media sosial.

4. Pemanfaatan teknologi digital dalam proses pembelajaran dapat meningkatkan minat dan motivasi belajar peserta didik, kualitas proses belajar, dan hasil belajar, namun perlu memperhatikan bebagai aspek kemampuan sumberdaya manusia maupun keamanan dan kesehatan guru dan peerta didik.

\section{REFERENSI}

[1] S. Noor-Ul-Amin, "An Effective use of ICT for Education and Learning by Drawing on Worldwide Knowledge, Research, and Experience: ICT as a Change Agent for Education," Sch. J. Educ., 2013.

[2] A. Ferrari, "Digital Competence in Practice: An Analysis of Frameworks," 2012.

[3] C. Amiama-Espaillat and C. Mayor-Ruiz, "Digital reading and reading competence: The influence in the $\mathrm{Z}$ generation from the Dominican Republic," Comunicar, 2017.

[4] H. Beetham and R. Sharpe, **** appendix for prompts taxonomy: Rethinking Pedagogy for a Digital Age: Designing for 21st Century Learning. 2007.

[5] E. E. Gallardo-Echenique, J. M. de Oliveira, L. Marqu\&amp, and F. Esteve-Mon, "Digital Competence in the Knowledge Society," J. Online Learn. Teach. U6 - ctx_ver $=Z 39.88$ $2004 \&$ ctx_enc $=$ info\%3Aofi\%2Fenc\%3AUTF-

$8 \& r f r \_i d=i n f o s i d /$ summon.serialssolutions.com \& rft_ val_fmt=infoofi/fmtkevmtxjournal\&rft.genre $=$ article $\&$ rft.atitle $=$ Digital + Competence + in + the + Knowledg e+Societ, 2015.

[6] G. Kress, Literacy in the new media age. 2003.

[7] European Commission, "Digital Agenda for Europe," Eur. Comm., 2014.

[8] I. V. P. Cortoni, "Digital Competence Assessment: A Proposal for Operationalizing the Critical Dimension.," J. Media Lit. Educ., 2015.

[9] K. Ala-Mutka, "Mapping digital competence: towards a conceptual understanding," 2011.

[10] L. Ilomäki, A. Kantosalo, and M. Lakkala, "What is Digital Competence?," Linked portal. Brussels Eur. Sch. ( ..., 2011.

[11] L. Ilomäki, S. Paavola, M. Lakkala, and A. Kantosalo, "Digital competence - an emergent boundary concept for policy and educational research,” Educ. Inf. Technol., 2016.

[12] C. A. Wolters, "Self-Regulated Learning and the 21st Century Competencies," Dep. Educ. Psychol. Univ. Houst. USA, 2010.

[13] K. Ananiadou and M. Claro, "21st Century Skills and Competences for New Millennium Learners in OECD Countries," OECD Educ. Work. Pap. No. 41, OECD Publ., 2009.

[14] P. Gilster and T. Watson, "An Excerpt from Digital Literacy,” Digit. Lit., 1997.

[15] A. Gruszczynska, G. Merchant, and R. Pountney, "'Digital futures in teacher education': Exploring open approaches towards digital literacy," Electron. J. e-Learning, 2013.

[16] G. Merchant, "Web 2.0, new literacies, and the idea of learning through participation," English Teach. 2009.

[17] Y. Eshet, Y. Eshet, and Y. Alkalai, "Digital Literacy: A Conceptual Framework for Survival Skills in the Digital era," J. Educ. Multimed. Hypermedia, 2004. 
[18] Y. Eshet-Alkalai, "Thinking in the Digital Era: A Revised Model for Digital Literacy," Issues Informing Sci. Inf. Technol., 2012.

[19] A. Martin and J. Grudziecki, "DigEuLit: Concepts and Tools for Digital Literacy Development," Innov. Teach. Learn. Inf. Comput. Sci., 2006.

[20] A. Martin, "Digital Literacy for the Third Age: Sustaining Identity in an Uncertain World," Identity, 2009.

[21] A. Calvani, A. Cartelli, A. Fini, and M. Ranieri, "Models and Instruments for Assessing Digital Competence at School Je-LKS Applications," 2008.

[22] A. Calvani, A. Calvani, A. Cartelli, A. Fini, and M. Ranieri, Journal of e-Learning and Knowledge Society. 2008.

[23] D. Riyanto, E. A. Sarwoko, and Kushartantya, "ELEARNING SEBAGAI MODEL PROSES PEMBELAJARAN BERBASIS TEKNOLOGI INFORMASI," Seminar, 2006.

[24] A. H. Suyanto, "Mengenal E-Learning," Technology, 2005.

[25] M. Sofwan Nugraha and U. Supriadi dan Saepul Anwar, "Pembelajaran PAI Berbasis Media Digital (Studi Deskriptip terhadap Pembelajaran PAI di SMA Alfa Centauri Bandung)," J. Pendidik. Agama Islam -Ta'lim, 2014.

[26] Z. B. Kassim, A. Razaq, and B. Ahmad, "EPembelajaran: Evolusi Internet Dalam Pembelajaran Sepanjang Hayat," 2010.

[27] M. Warschauer, "The paradoxical future of digital learning," in Learning Inquiry, 2007.

[28] W. Barber, S. King, and S. Buchanan, "Problem based learning and authentic assessment in digital pedagogy: Embracing the role of collaborative communities," Electron. J. e-Learning, 2015.

[29] J. Voogt, O. Erstad, C. Dede, and P. Mishra, "Challenges to learning and schooling in the digital networked world of the 21 st century," J. Comput. Assist. Learn., 2013.

[30] M. Northcote, P. Mildenhall, L. Marshall, and P. Swan, "Interactive whiteboards: Interactive or just whiteboards?," Australas. J. Educ. Technol., 2010.

[31] G. HamAttwell, "Personal Learning Environments the future of eLearning ?," eLearning Pap., 2007.

[32] M. Thomas and H. Thomas, "Using new social media and Web 2.0 technologies in business school teaching and learning," J. Manag. Dev., 2012.

[33] A. Russo, J. Watkins, and S. Groundwater-Smith,
"The impact of social media on informal learning in museums," EMI. Educ. Media Int., 2009.

[34] B. Holmes and J. Gardner, e-Learning: Concepts and practice. 2006.

[35] R. Eck van, "Digital Game-Based Learning: It's Not Just the Digital Natives Who Are Restless," Educ. Rev., 2006.

[36] K. Hayden, Y. Ouyang, L. Scinski, B. Olszewski, and T. Bielefeldt, "Increasing Student Interest and Attitudes in STEM: Professional Development and Activities to Engage and Inspire Learners," Contemp. Issues Technol. Sci. Teach. Educ., 2011.

[37] J. Sefton-Green, "Literature review in informal learning with technology outside school," Perform. arts, 2004.

[38] F. Cornillie, G. Clarebout, and P. Desmet, "The role of feedback in foreign language learning through digital role playing games," Procedia - Soc. Behav. Sci., 2012. 